\title{
Artikkeli
}

\section{Journalismin totuudenmukaisuus: luottamussuhde yleisöjen kanssa}

\begin{abstract}
Journalistin ohjeet velvoittavat totuudenmukaiseen tiedonvälitykseen. Valeuutisten ja disinformaation levitessä samanaikaisesti relativististen tutkimussuuntausten kanssa journalismin kulmakivi eli yleisöjen luottamus on joutunut koetukselle. Erottelu totuudenmukaisen tiedon ja informaation välillä hankaloituu, jos journalismin tiedolliset käsitteet objektiivisuus ja totuudenmukaisuus kyseenalaistetaan journalismissa ja sen tutkimuksessa. Journalismi voi elää vain yleisöjensä luottamuksesta, ja kansalaiset tarvitsevat totuudenmukaista ajankohtaistietoa tehdäkseen perusteltuja yksityisiä ja yhteiskunnallisia päätöksiä. Tässä viestinnänfilosofisessa artikkelissa totuudenmukaisuutta tarkastellaan pragmatistisen filosofian tietokäsityksen valossa, mikä tarjoaa rikasta käsitteellistä sisältöä journalismin tiedollisille ydinkäsitteille journalismin käytännöille ja tutkimukselle. Artikkeli tarjoaa viitekehyksen käsitteellisille välineille, joilla voidaan erottaa journalismi muusta ajankohtaisinformaatiosta itsenäisenä tietokäytäntönä - niin toimintana kuin tutkimuskohteena. Totuudenmukaisuus ja objektiivisuus ymmärretään tiedollisina käsitteinä, jotka voivat taata luottamussopimuksen journalismin ja yleisöjen välillä sekä siten ylläpitää ja kehittää liberaalia demokratiaprosessia.
\end{abstract}

AVAINSANAT: Journalismi, pragmatismi, totuudenmukaisuus, objektiivisuus, luottamus

Motto

Journalistin velvollisuus on pyrkiä totuudenmukaiseen tiedonvälitykseen.

- Journalistin ohjeet 8 . §.

ournalismin asema yhteiskunnassa riippuu pitkälti yleisöjen luottamuksesta. Journalistinen tieto koskee tapahtumia, tekoja ja ilmiöitä, joihin yleisöillä ei ole suoraa tiedollista yhteyttä. Tiedon välittyneisyys journalismin kautta edellyttää siksi tiedon luotettavuutta, mutta luottamus on viime aikoina kyseenalaistettu monella rintamalla (ks. Edelman 2020; Ramonet 2011; Rusbridger 2018). Euroopan komission barometrin mukaan vain noin puolet väestöstä vastaa luottavansa mediaan instituutiona, Suomessa määrä on noin 70 prosenttia (EU 2019). Sanomalehtien Liiton tutkimuksessa 
(2018) sosiaalisen median kansalaisilta saamat arvosanat ovat heikentyneet merkittävästi. Silti tiedettä koskevan tiedon lähteistä perinteisten joukkoviestimien rinnalle on kohonnut internet (internet, tietoverkot ja sosiaalinen media, 74 \%) (Tiedebarometri 2019). Suomessa luotetaan yhä suhteellisesti paljon uutisiin, mutta vaihtoehtomediat ja valemediat ovat olleet vuosia nousussa (Sivonen \& Saarinen 2018; ks. McNair 2018).

Suomalaisyleisöjen luottamusta havainneessakin tutkimuksessa perinteisesti luotettavana pidetty, journalistisia uutisia tuottava media on häviämässä viihdemedialle (Reuters 2019). Yleisöjen luottamusta journalismiin ovat heikentäneet valeuutisiksi ja vaihtoehtoisiksi totuuksiksi kutsutun paikkansapitämättömän informaation nopea leviäminen internetissä ja sosiaalisessa mediassa, aikamme kutsuminen "totuudenjälkeiseksi" sekä journalismin tutkimuksessa yleistynyt totuudellisuuden käsitteen vältteleminen (Niiniluoto 2019, 10; ks. esim. Cooke 2017; Vihma ym. 2018; Vosoughi ym. 2018). Selvät valheet taas vaikuttavat suoraan tai epäsuorasti vaalituloksiin, kun ihmiset uskovat saamaansa informaatioon (O'Connor \& Weatherall 2019, 3-5).

Hautakankaan ja Ahvan $(2018,294)$ mukaan kansalaisten luottamus demokraattisen yhteiskunnan toimintaan on pitkälti journalismin tuottaman julkisuuden varassa. Journalismi kantaa siis suurta vastuuta luottamuksesta, jota disinformaatio ja relativismi heikentävät. Niiden lisäksi journalismin autonomiaa totuudenmukaista ajankohtaistietoa tavoittelevana käytäntönä uhkaavat taloudellisten paineiden aiheuttama kiire ja siihen liittyvä tukeutuminen ulkopuolisten taloudellisten ja poliittisten viestijöiden ja tiedottajien valmiisiin aineistoihin. Journalismi kadottaa identiteettinsä, jos yleisöjen luottamus sen tarjoamaan tietoon katoaa.

Journalismin luotettavuuden takeeksi on säädetty Journalistin ohjeissa pykälä, joka velvoittaa journalistit totuudenmukaiseen tiedonvälitykseen. Tietojen hankkimista ja julkaisemista koskeva ohjeistus (pykälät 8-16) pyrkii ohjaamaan journalisteja kohti asetettua tavoitetta. Siksi tieto tulee erottaa tiukasti muusta informaatiosta. Niin Journalistin ohjeissa kuin tässäkin artikkelissa puhutaankin nimenomaan tiedosta.

Julkisen sanan neuvoston valvomat Journalistin ohjeet ovat näin yksityiskohtaisempia kuin sananvapauslaki. Toisaalta Journalistin ohjeilla ei ole lainvoimaa, vaan ne toimivat alan itsesääntelyn normeina. Yleisöjen luottamusta journalismiin ohjeet eivät voi sellaisinaan taata, koska keskeinen totuudenmukaisuuden käsite jää ohjeissa tiedollisesti tarkentamatta.

Totuudenmukaisuuden lisäksi ilman käsitteellisesti selkeää sisältöä jäävät myös tiedon ja sen välittyneisyyden käsitteet. Objektiivisuutta ei Journalistin ohjeissa mainita, mutta käsitteestä käytiin vilkasta keskustelua 1980-luvulla Suomessa (Hemánus \& Tervonen 1980; Tervonen 1986). Tuolloin objektiivisuutta käsiteltiin kuitenkin "joukkotiedotuksen" ominaisuutena, joka hahmoteltiin journalistisiin teksteihin yhteensopimattoman totuuden korrespondenssi- eli vastaavuusteorian kautta. Objektiivisuushahmotelmat tehtiin aikana ennen internetiä ja sosiaalista mediaa, eikä huomiota kiinnitetty journalismiin itsenäiseksi rajattuna tietokäytäntönä (Lehtinen 2016; vrt. Niiniluoto 1995). Keskeiset tiedolliset käsitteet tarvitsevatkin uuden hahmotelman journalismin luotettavuuden tähden. 


\section{Tutkimusasetelma: mitä luottamus edellyttää}

Yhteisymmärrys journalismin tiedollisista käsitteistä voisi ylläpitää ja kehittää luottamusta journalistien ja yleisöjen välillä, kun totuudenmukainen tieto erotetaan misinformaatiosta ja disinformaatiosta, ja siten tuetaan paikkansapitävään tietoon tukeutuvaa demokratiaprosessia. Käsitteellisesti rajattu journalismi tarjoaisi myös journalismin tutkimukselle selkeärajaisen kohteen.

Totuus, objektiivisuus ja totuudenmukaisuus on viime vuosina kuitenkin jätetty lähes kokonaan pois journalismista ja sen tutkimuksesta, vaikka joitakin poikkeuksia on (ks. esim. Malmberg 2017). Hemànus ja Tervonen (1980; ks. Niiniluoto 1995) pitivät keskustelua tiedollisista käsitteistä yllä vielä 1990-luvulle saakka, mutta sittemmin ne ovat jääneet muun tutkimuksen varjoon. Ilman näitä käsitteitä journalistinen tieto jää arvioitavaksi vain postmodernin relativismin mukaisesti. Se tarkoittaa karkeasti ottaen kaikkien väitteiden "yhtäläistä paikkansapitävyyttä" (Boghossian 2006, 5). Tämänkaltainen tiedollinen relativismi ei salli erottaa paikkansapitävää tietoa sen kanssa kilpailevasta, usein harhaanjohtavasta informaatiosta, jota puolustetaan kaikkien äänien samanarvoisuudella, riippumatta uskottavammasta evidenssistä tai paremmista perusteluista. Näin tiedolliset, käsitteelliset ja luottamukseen liittyvät ongelmat kytkeytyvät saumattomasti journalismin laajempiin eettisiin kysymyksiin ja journalistin velvollisuuksiin (Seth 2020).

Journalistit kuitenkin kertovat sitoutuneensa yhä Journalistin ohjeisiin, vaikka normien merkityksestä ei ole yhteisymmärrystä (Martevo 2019; ks. Luostarinen \& Raittila 2014; Pöyhtäri ym. 2014; Reunanen \& Koljonen 2015). Jorma Mäntylän (2008, 61) mukaan on vaikea kuvitella journalismietiikkaa, joka ei perustuisi totuudellisuuteen ja tiedonvälityksen objektiivisuuteen. Journalismin tiedolliset ydinkäsitteet kaipaavat nimenomaan filosofista tutkimusta, koska "[t]otuudenmukaisuus ja tietojen oikeellisuus on Journalistin ohjeiden filosofinen perusta" (emt., 64). Lisäksi yleisöt haluavat, että journalismi paitsi paljastaa ja selittää ongelmallisia tapahtumia ja ilmiöitä, myös tarjoaa ratkaisuehdotuksia askarruttaviin asioihin (O'Donovan 2014). Siitä huolimatta disinformaatio ja relativismimyönteiset näkemykset näyttävät saavan lisää tilaa ja vaikutusvaltaa, vaikka niiden leviämisellä voi olla yhteiskunnallisesti jopa katastrofaalisia seurauksia (O'Connor \& Weatherall 2019; ks. Boghossian 2006, 5).

Jos toimiva ja luotettava journalismi on demokratian edellytys, totuudenmukaisuus on luotettavan ja selittävän journalismin ennakkoehto samoin kuin avoimuus journalismin menetelmistä ja niitä ohjaavista normeista. Empiirinen tutkimus on jo taannoin tiivistänyt, että journalismissa "yleisöjen kosiskelu ja markkinakilpailu [...] liitetään kansalaisten näkemyksissä poikkeuksetta kielteiseen kehitykseen. Sisällöllisesti medialta toivotaan nykyistä syvällisempää ja analyyttista uutisointia." (Karppinen ym. 2010, 40-43.) "Objektiivisuuden puute" häiritsee yleisöjä etenkin verkkomediassa (emt., 43), mutta käsitteet objektiivisuus ja totuudenmukaisuus jäävät tutkimuksessa vaille artikulointia tai selitystä. Journalismia on vaikea erottaa muista ajankohtaisinformaation tarjoajista itsenäisenä käytäntönä, joka tuottaa objektiivisin menetelmin totuudenmukaista ja luotettavaa tietoa (Maras 2013). 
Huolta aiheuttaa sekin, että "totuus" ja "totuudenmukaisuus" kirjoitetaan mediassa ja sen tutkimuksessa yhä useammin lainausmerkeissä. Käsitteisiin kohdistunut relativistinen kritiikki ja disinformaation kasvu ovat horjuttaneet käsitteiden uskottavuutta ja siten niiden käyttökelpoisuutta. Tässä artikkelissa tutkitaan journalismin tiedollisesti keskeisiä käsitteitä pragmatistisen filosofian kontekstissa, minkä toivotaan tarjoavan uutta sisältöä käsitteille ja niitä koskevalle keskustelulle journalistien, yleisöjen ja journalismin tutkijoiden parissa. Keskustelun edellytyksenä voi näet olla jonkinasteinen yhteisymmärrys siitä, mitä käsitteillä tarkoitetaan.

Artikkelin tutkimusmenetelmänä on siis käsiteanalyysiin erikoistunut filosofia, mutta huomionarvoisesti nimenomaan käytäntöä ja toimintaa korostava pragmatistinen filosofia. Artikkeli tukeutuu muun journalismin totuudenmukaisuutta käsittelevän filosofisen kirjallisuuden vähäisyyden takia pitkälti Stephen J. A. Wardin (2010; 2004) hahmotelmaan "pragmaattisesta objektiivisuudesta" sekä kirjoittajan väitöskirjaan ja muihin julkaisuihin samoista teemoista (Lehtinen 2019; 2016; 2015; 2013). Lähdeaineiston puuttuminen selittää myös pitkän ja monialaisen kirjallisuusluettelon: aineistoa on pitänyt hakea usealta suunnalta filosofisen ajattelun soveltamiseksi journalismin käytäntöön ja tutkimukseen.

Uutta artikkelissa on Journalistin ohjeiden tiedollisen ydinkäsitteen totuudenmukaisuuden avaaminen ja selkeyttäminen. Tutkimus edellyttää siksi myös ei-pragmatististen filosofien käsityksiä, jotka ovat aihepiirin kannalta relevantteja. On myös huomioitava, että pragmatismi itsessään ei ole yhtenäinen koulukunta, vaan pikemminkin filosofinen ohjelma, jossa on myös monia sisäisiä erimielisyyksiä. Pragmatismista on kuitenkin nostettavissa esiin muutamia keskeisiä oivalluksia, jotka suurin osa pragmatisteista jakaa (Bernstein 2010). Näitä yleisiä suuntaviivoja noudattaen artikkelissa pyritään tarjoamaan tulkintakehys käsitteille.

Artikkelin motiivi onkin hahmotella journalismille ja sen tutkimukselle filosofinen mutta käytäntöä painottava viitekehys tiedollisten käsitteiden rikastuttamiseksi sekä luonnostella viestinnänfilosofiset puitteet journalismin ja sen yleisöjen suhteelle. Käsitteellisesti perusteltu ja avoimesti artikuloitu totuudenmukaisuus voi toimia journalistien luottamussopimuksena yleisöjen kanssa, kun journalistit saadaan pohtimaan ja selittämään yleisöilleen journalistisen prosessin, kuten tiedon hankkimisen ja esittämisen, eri vaiheita sekä niiden suhdetta totuudenmukaisuuteen. Journalismin tutkimus puolestaan saa näin selkeärajaisen kohteen, kun journalismi erotetaan internetin ja sosiaalisen median informaatiotulvasta autonomisena tietokäytäntönä (Rupar 2010, 3-10).

Journalismia tarkastellaan sen monimuotoisuudesta huolimatta tässä artikkelissa yhtenäisenä käytäntönä, sillä uutisten lisäksi myös mielipiteellisemmät juttutyypit, kuten pääkirjoitukset sekä toimittajien kirjoittamat kolumnit ja blogit ovat sitoutuneet totuudenmukaiseen tietoon. Muussa tapauksessa kyseessä on vapaa mielipiteenilmaisu tai disinformaatio, eikä tämän artikkelin aihepiirin rajaama journalismi. Journalistisen tuotteen tyypistä riippumatta ilmaistujen asioiden ja käsiteltyjen tapahtumien ja ilmiöiden pitää olla todellisia ja niistä esitettyjen väitteiden totuudenmukaisia, jotta tuote olisi journalismia. Juttutyypin ilmoittaminen yleensä auttaa yleisöä 
erottamaan uutiset ja muut "faktuaaliset" jutut kantaaottavista pääkirjoituksista, blogeista ja kolumneista.

Artikkelin alussa esitellään journalismin kohtaamia tiedollisia ja eettisiä haasteita. Sitten perustellaan, miksi juuri pragmatistinen filosofia soveltuu parhaiten journalismin käsitteelliskäytännölliseksi tulkintakehykseksi. Tämän jälkeen keskeiset tiedolliset käsitteet objektiivisuus ja totuudenmukaisuus hahmotellaan uudelleen tarjottua taustaa vasten. Lopuksi arvioidaan, miksi ja miten pragmatistisesti ymmärretyt tiedolliset käsitteet voivat edistää journalismin ja sen yleisöjen välistä luottamussopimusta.

\section{Journalismi ja filosofia}

Journalistin ohjeiden vaatimus "totuudenmukaisesta tiedonvälityksestä" saa tulkinnalliseksi tuekseen listan konkreettisia tiedonhankinnallisia ohjeita (Journalistin ohjeet pykälät 9-16). Itse totuudenmukaisuuden käsite jää kuitenkin hämäräksi, vaikka se erottaa tiedon pelkästä informaatiosta (Niiniluoto 1996). Tämän viestinnänfilosofisen tutkimuksen tavoitteena on tehdä selkeä demarkaatio journalismin ja muun ajankohtaisinformaation välillä. Jälkimmäisiä edustavat muun muassa viihde sekä tahaton misinformaatio ja tahallinen disinformaatio (Stahl 2010).

Journalismi on erotettava myös mediasta journalismin erilaisina alustoina. Journalistista tietoa voidaan esittää ja tutkia useassa mediassa, mutta journalistinen tieto edellyttää totuudenmukaisuutta. Media puolestaan kattaa kaikki alustat, joilla välitetään myös ei-journalistista informaatiota. Internetin ja sosiaalisen median kautta miljoonat elleivät miljardit inmiset voivat levittää reaaliajassa informaatiota, josta suuri osa on mielipiteitä, valeuutisia ja suoranaista propagandaa. Kun alusta alkaa käyttää toimituksellisia menetelmiä, kuten Twitterin faktantarkistuslinkit presidentti Donald Trumpin twiiteissä, alusta astuu lähemmäs journalismia (Yle 27.5.2020). Toisaalta myös journalistista sisältöä on voitu välittää somealustoillakin niiden alusta asti.

Perinteisesti filosofiassa tieto on määritelty totena ja hyvin perusteltuna uskomuksena. Platonilta periytyvä määritelmä sopiikin totuusvaatimuksensa kanssa yksittäisiin väitelauseisiin, joiden suhteen totuutta useimmissa filosofisissa totuusteorioissa ja totuuden määritelmissä tutkitaan. Vähemmän tutkittu totuudenmukaisuuden käsite on laajempi käyttöalaltaan, ja siksi sitä voidaan soveltaa yksittäisten väitelauseiden sijasta journalistisiin teksteihin kuten uutisiin ja reportaaseihin kokonaisuuksina, erotettuina yksittäisistä tosiasioista, joista ne koostuvat (ks. Williams 2002).

Tässä artikkelissa tarkastellaan nimenomaan journalismia ja journalististen tekstien totuudenmukaisuutta, jolloin huomio kiinnittyy pragmatistisen filosofian mukaisesti tiedonhankintaprosessiin ja sen luotettavuuteen totuudenmukaisen tiedon välineenä. Journalismin erottaminen muusta informaatiosta itsenäisenä tietokäytäntönä palvelee journalismia ja sen tutkimusta erityisesti sosiaalisen median informaatio- 
heimoutumisen aikana (Hopf ym. 2019). Totuudenmukaisuus takaa, että tieto on paikkansapitävää kaikille.

Tieto kuuluu filosofisen tutkimuksen erikoisalueisiin. Toisin kuin muilla yhteiskunnallisen elämän kannalta keskeisillä aloilla - kuten politiikalla, oikeudella, historialla, tieteellä, taiteella ja uskonnolla - journalismilla ei kuitenkaan ole toistaiseksi omaa filosofiaa akateemisena oppiaineena tai suuntauksena (Baggini 2003). Suoran tutkimuskirjallisuuden vähäisyydestä huolimatta filosofian merkitys journalismille ja sen tutkimukselle on laajasti tunnustettu: Journalismin tutkimuksen näkökulmat liittyvät aina johonkin filosofiseen käsitykseen tiedosta, "käsitykseen todellisuuden ja ihmisen suhteesta ja tietämisen mahdollisuuksista" (Kunelius 2003, 16). "[J]ournalismin todenmukaisuus- ja objektiivisuus- yms. ongelmat eivät voi ratketa hyvin ilman filosofian ja yleensä tieteen apua" (Hemánus 1995, 32). Wiion (1975) mukaan journalismin objektiivisuuden ja totuudenmukaisuuden mahdollisuus riippuu tiedostetuista ja tiedostamattomista filosofisista näkemyksistä. Käytännön journalismikin tarvitsee filosofista ajattelua, sillä "perustavaa laatua olevilla filosofisilla opeilla on erittäin merkittäviä seurauksia journalismin käytännön työn kannalta" (Niiniluoto 1995, 9). Pragmatismin klassikko John Dewey on yleistänyt: "Yhteiskuntafilosofia ilman systemaattista yhteiskuntatutkimusta on tyhjää, filosofian unohtava empiristinen yhteiskuntatiede on sokeaa" (sit. Kilpinen ym. 2008, 10; vrt. James 2008 [1907]; ks. Pihlström 1997; Rolin ym. 2006). Pragmatismia onkin sovellettu yhteiskuntatieteiden filosofiassa, mutta ei juuri aiemmin journalismin tai sen tutkimuksen tarkasteluissa (ks. Kilpinen ym. 2008).

Journalismin käytäntö ja sen teoreettinen tutkimus näyttävät kietoutuvan yhteen yllä esitetyissä kommenteissa journalismin filosofisesta taustasta. Filosofiset totuusteoriat vaikuttavat kuitenkin sellaisinaan yhteensopimattomilta journalismin ja sen tutkimuksen tarpeisiin (Malmberg 2017). Esimerkiksi arkiajattelun kanssa sopusointuinen totuuden korrespondenssi- eli vastaavuusteoria, jonka mukaan lause tai uskomus on tosi, mikäli sillä on tosiasiallinen vastine todellisuudessa, sortuu pitämään kieltä tai mieltä ikään kuin todellisuuden peilinä, joka heijastaa todellisuudessa vallitsevia asiantiloja. Teoria perustuu tietävän subjektin ja tiedon kohteena olevan objektin erotteluun, jolle pragmatistinen filosofia ei näe perusteita. Ihmiset ovat jatkuvassa vuorovaikutuksessa itseään ympäröivän aineellisen ja sosiaalisen todellisuuden kanssa, joten subjektin ja objektin suhdetta on mielekkäämpää tarkastella jatkumona kuin toisistaan erillisinä entiteetteinä. Ihminen organismina on osa todellisuutta, josta hän tavoittelee tietoa (Dewey MW 4, 7-8).

Tiedon subjektin ja objektin erottaminen toisistaan totuuden korrespondenssiteorian olettamalla tavalla uhkaa jättää todellisuuden tiedon ulkopuolelle, koska tieto todellisuudesta voidaan tällöin ymmärtää subjektiiviseksi tai sosiaalisesti rakentuneeksi (ks. Niiniluoto 2002; "pragmatistisesta realismista" ks. Pihlström 1996). Todellisuus voi tällöin jäädä tiedollisesti tavoittamattomaksi. Tämä sallii relativistisen puheen "vaihtoehtoisista faktoista" tai "jokaisen omasta totuudesta". Siksi subjektiivisuutta ja objektiivisuutta onkin parempi tarkastella jatkumona, jossa tietoa tavoittelevan subjektin tai yhteisön tavoitteena on pyrkiä asteittain ja menetelmällisesti kohti objektiivisuutta tiedollisissa raporteissaan (ks. Nagel 1986). "Subjektit" elävät "objek- 
tiivisessa" todellisuudessa luonnontieteiden tarkoittamalla tavalla. (Ks. Figdor 2010; Kovach \& Rosenstiel 2007; vrt. Lichtenberg 2000.) Toisaalta objektiivisuus on liian tärkeä käsite, jotta siitä voitaisiin "tiedon subjektiivisuuden" nimissä luopua (Hildebrand 2011; Meyers 2010, 132). Disinformaatiotulvassa sen merkitys korostuu, mutta tuo merkitys on kaikkea muuta kuin selvä. Käsitettä käytetään monessa eri tarkoituksessa.

Suomalaisista Journalistin ohjeista objektiivisuuden käsite kokonaan puuttuu. Euroopan maiden "journalistin ohjeita" (ks. https://research.uta.fi/ethicnet/country/) vertaillessa huomataan, että objektiivisuus ymmärretään useassa eri merkityksessä. Objektiivisuudella tarkoitetaan yhtäällä todellisuuden ominaisuutta, toisaalla journalistilta odotettua ominaisuutta; yhtäällä journalistisen tekstin ominaisuutta ja toisaalla journalistisen instituution ominaisuutta; ja näiden lisäksi tarkkuutta, reiluutta, tasapuolisuutta, puolueettomuutta tai läpinäkyvyyttä (vrt. Boudana 2015). Objektiivisuuden käsite tuskin parantaa journalismin käytäntöä tai lisää sen luotettavuutta ilman jonkinasteista yhteisymmärrystä käsitteen sisällöstä tai käyttöalasta.

Toisaalta käsite voi johtaa harhaan, jos journalistisen jutun tavoitteeksi asetetaan esimerkiksi reiluus tai tasapuolisuus (vrt. Journalistin ohjeet 9-16 §). Tällöin esimerkiksi perusteluiltaan epäsuhtaiset näkemykset voidaan esittää journalismissa samanarvoisina, vaikka todistusaineisto tai paremmat perustelut puhuisivat selvästi jonkin näkemyksen puolesta. Journalistin tulee olla ohjeiden mukaan todenpuhumisen puolella. "Totuus" ei löydy yksinkertaisesti asettamalla jutussa kaksi erimielisyyttä vastakkain. Voimakkaan kritiikin kohteelle tulee tarjota mahdollisuus "tasapainottavaan" puheenvuoroon ja erilaisia ääniä on syytä kuunnella (vrt. Journalistin ohjeet 21-25 §). Tästä ei kuitenkaan seuraa, että kaikki väitteet olisivat tiedollisesti samanarvoisia, yhtäläisen paikkansapitäviä.

\section{Tieto tutkimuksena}

Journalistisen totuuden ymmärtäminen todellisuuden peilaamisena perustuu metaforiseen ajatteluun, jonka mukaan tieto käsitetään eräänlaisena intellektuaalisena "näkemisenä". Tätä käsitystä vastaan argumentoi pragmatismin klassikoista erityisesti John Dewey (1859-1952), joka korosti sen sijaan tiedon toiminnallisuutta. (Dewey 1999[1929]; 2012[1919].) Koska ihminen organismina elää fyysisessä todellisuudessa ja kielikykyisenä kädellisenä myös saman todellisuuden sosiaalisissa ja kulttuurisissa ulottuvuuksissa, tietäminen on tutkimusta ympäröivässä maailmassa. Tiedoksi voidaan kutsua tuon dynaamisen tutkimuksen tuloksia, jotka ovat aina tilapäisiä ja epävarmoja, mutta korjaus- ja kehityskelpoisia. (Dewey LW 12, 16.) Tiukka erottelu tietävän subjektin ja tiedon kohteena olevan objektin väliltä katoaa, ja sitä myöten myös objektiivisuus on syytä muotoilla uudestaan, samoin totuudenmukaisuus. Koska tieto on tutkimustuloksia, huomio tulee kiinnittää tutkimusmenetelmien luotettavuuteen.

Journalistisella tiedolla tarkoitetaan tässä artikkelissa sellaista ajankohtaisinformaation hankintaa, jonka harjoittajat ovat sitoutuneet Journalistin ohjeiden tiedollisiin ja eettisiin normeihin. Journalismia tarkastellaan pragmatistisesti tutkimuksena, 
jolloin huomio keskittyy tiedonhankintamenetelmään riippumatta journalismityypistä. Mielipiteelliset journalistiset tuotteet, kuten yllä mainittiin, erotetaan ilmoittamalla juttutyyppi.

Filosofi Ilkka Niiniluodon - arvovaltaisen pragmatismikriitikon - mukaan "pragmatismi on käsitteiden selventämiseen pyrkivä metodi" $(2002,118)$. Niiniluodon kiteytys kuvaa osuvasti tämän artikkelin tarkoitusta selventää objektiivisuuden ja totuudenmukaisuuden käsitteitä journalismin autonomian ja siten yleisöluottamuksen takuiksi. Talousvaikeuksien ja kiireen kaltaisia journalismin ongelmia ei ole mahdollista käsitellä perusteellisemmin, mutta on huomautettava, että yleisöjen kiinnostuksen journalistiseen tietoon voi toivoa nousevan sitä mukaa kun journalismin luotettavuus yleisöjen silmissä paranee ja kiinnostavuus nostetaan arvoksi journalistista tuotetta laadittaessa yhteiskunnallisesti ja inhimillisesti tärkeistä aiheista. "Klikkijournalismi" ei tarkoita journalismin taantumaa, jos vetävillä otsikoilla ja sisällöillä saadaan yleisöt kiinnostumaan demokratiaprosessia tukevasta journalismista.

Käsitteiden selventämisessä ensimmäiseksi on syytä tarkastella tietoa tutkimuksena, jonka filosofinen avainkäsitys deweyläisessä pragmatismissa on kokemus (Dewey 1958/1925; ks. Pihlström 2002). Kokemus kiinnittää ympäristöään eli todellisuutta tutkivan tietoa hankkivan ihmisen ympäristöönsä eli todellisuuteen nimenomaan käytännöissä ja toiminnassa (Kilpinen ym. 2008, 7). Myös journalistisessa tiedonhankinnassa tutkimuksellisuus on käytännöllinen lähtökohta, ja siksi tutkivaa journalismia voi pitää kaiken journalistisen toiminnan prototyyppinä, jonka eriasteisia variantteja erilaisissa journalistisissa prosesseissa ja tuotteiden laatimisessa huomataan taustalla. Myös kantaaottavat journalistiset tuotteet täytyy perustaa mahdollisimman objektiivisella tiedonhankintamenetelmällä hankittuun totuudenmukaiseen tietoon. (Käsitteellisestä prototyypistä ja käytäntöjen perheyhtäläisyydestä ks. Appelqvist 2010.)

Journalismin tietokäytännön yleinen tutkimuksellisuus tulee siis selkeimmin esille tutkivaksi kutsutussa journalismityypissä, jossa perehdytään tapahtuman tai ilmiön syihin ja taustoihin. Siksi tutkivan journalismin laadukkaimpia - lähimmäs totuudenmukaista raportointia pääseviä - toteutuksia voidaan pitää malliesimerkkeinä muulle journalistiselle tutkimukselle ja sen työprosessin eri vaiheille, joita on eritellyt Heikki Kuutti (2015). Myös mielipiteelliset kolumnit, blogit ja pääkirjoitukset - ollakseen journalismia - joutuvat tiedonhankinnassaan tukeutumaan pragmatismin tarkoittamaan tutkimukseen. Tämä lähtökohta tukee myös yleisöjen luottamusta, sillä valtaosa suomalaisista toivoo internetaikanakin tiedotusvälineisiin lisää uutisia ja erityisesti tutkivaa journalismia (MTV Uutisten mediakysely, kesäkuu 2014). Pragmatistiseen tutkimuskäsitykseen kuuluvatkin yleisellä tasolla tutkivaan journalismiin yhdistetyt piirteet kuten kriittisyys, dynaamisuus, itseäänkorjaavuus ja perusteellisuus, joiden tukena on Journalistin ohjeiden lisäksi uutiskriteerien ja muiden tiedollisten normien ohjaus. Tässä mielessä journalismi ei ole arvovapaata: totuudenmukaisuus on journalismin korkein arvo, eikä tosiasioistakaan voida puhua erotettuina niitä rajaavista arvoista (Putnam 1990).

Pragmatismin hengessä journalismin tiedollisten käsitteiden selventämiseksi on huomattava, että keskeisten termien ja käsitteiden merkitykset - joita artikkelissa nyt 
pyritään käytännön filosofialla rikastuttamaan - tulee arvioida niiden käytännöllisten seurausten perusteella tiedollisessa tutkimuksessa (Dewey MW 10: 39-43). Tutkimuksella voi olla monia erilaisia muotoja, mutta ne toteutetaan aina jostakin näkökulmasta, tietyssä historiallisessa ja kulttuurisessa tilanteessa, ja palvelemaan tiettyjä päämääriä kuten totuudenmukaista tiedonvälitystä ja siten yleisöluottamuksen voittamista (Nagel 1986).

Tieto on dynaamista, sillä se ei voi olla passiivista todellisuuden "peilaamista" (Hildebrand 2013, 57; ks. Bernstein 2010). Yhtäältä yksittäiset tosiasiat tai totuudet väitelauseiden tai kuvien tasolla eivät riitä journalistisen jutun kuten uutisen totuudenmukaisuuden takaajiksi, koska myös disinformaatiossa voidaan käyttää kontekstistaan irrotettuja tosiasioita. Niin usein tehdäänkin harhaanjohtavan informaation vakuuttavuuden lisäämiseksi. Toisaalta "koko totuutta" mistään asiasta ei voida kertoa, koska minkä tahansa tapahtuman tai ilmiön kausaalisten syysuhteiden jatkumo venyy periaatteessa loputtomiin, ja "koko totuus" edellyttäisi mahdotonta "näkökulmaa ei-mistään" (Nagel 1986). Toisaalta kaiken kertominen, vaikka se olisikin mahdollista, olisi yhtä hyödytöntä kuin maailman kokoinen 1:1-kartta. Siksikin on perusteltua keskittyä totuudenmukaisuuteen, joka mukailee esimerkiksi uutistekstissä tiedonhankinnan menetelmällisessä prosessissa varmennettuja totuuksia.

Yksittäiset totuudet ovat journalististen väitelauseiden tai valokuvien kaltaisia otoksia todellisuudesta rajatuista tapahtumista ja ilmiöistä. Vastaavasti uutiset ovat todellisuuden kausaalisuhteita noudattavan tositarinan kaltaisia "pysäytyskuvia" todellisuuden tapahtumisen jatkuvasta ja pysäyttämättömästä virrasta. Yksittäisiä totuuksia joudutaan tulkitsemaan totuudenmukaisuuden saavuttamiseksi.

\section{Pragmaattinen objektiivisuus}

Tiedolliset ja muut käsitteet ymmärretään filosofiassa usein representaation eli esittämisen kautta. Mieli representoi käsitteellisesti ("peilaa") todellisuutta (Knuuttila \& Lehtinen 2010). Representaatioita on harhaanjohtavaa tarkastella "mielensisäisinä merkityksinä", koska ideat ja käsitteet eivät sijaitse mielessä kiinteinä kuin piparit purkissa (Määttänen 2009). Sama voidaan sanoa käsitteiden yhteydestä toisiin käsitteisiin (Godfrey-Smith 2019). Kielitoimiston sanakirjassa totuus saa seuraavan kuvauksen: "se mikä on totta, vastaa todellisuutta; tosiasia". Totuudenmukaisuus samastuu "totuudenmukaiseen selostukseen". Pragmatistiseen traditioon liitetty W. V. O. Quine (1969) on kuitenkin huomauttanut, että käytössä eläviä käsitteitä ei voida vangita kiinteisiin sanakirjamääritelmiin. Käsitteet nimittäin liittyvät erottamattomasti uskomuksiin. Esimerkiksi ennen Benjamin Franklinin työtä suurin osa niin sanotuista sähkömiehistä piti totena lausetta "sähkö on neste". Enää lausetta ei pidetä totena, koska sähkön käsitteeseen kuuluu nykyään muun muassa elektroneja. Ei voida erotella, muuttuiko sähkön merkitys vai sähköä koskevat uskomukset (ks. Murphy 1990, 98; Quine 1969). Pragmatistisesti ottaen merkitykset ja uskomukset kiinnittyvät toisiinsa ja tulevat mielekkäiksi käyttöyhteyksissään. Myös objektiivisuuden ja totuudenmukai- 
suuden kaltaiset käsitteet liittyvät tiiviisti niitä koskeviin uskomuksiin, joita pragmatismi muuttaa. Käsitteet ovat muovautuvia ja saavat merkityksensä niiden käytössä (Hutchinson \& Read 2013; ks. Wittgenstein 1997[1953]).

Ensinnäkin sen sijaan, että objektiivisuuden käsite ymmärrettäisiin pelkäksi subjektiivisuuden vastakohdaksi, voitaisiin käsitteiden nähdä sijaitsevan yhdellä ja samalla tiedollisella subjekti-objekti-asteikolla. Koska tiedollisessa toiminnassa eli tutkimuksessa journalisti toimii vuorovaikutuksessa fyysisen ja sosiaalisen ympäristönsä kanssa yhteisöllisten normien varassa, hän liikkuu tiedollisesti asteikolla tutkimuksen edetessä subjektiivisista lähtökohdistaan eli ennakko-oletuksistaan sekä kognitiivisista vääristymisistään kohti kattavampaa käsitystä tiedon kohteesta eli objektista (Nagel 1986). Vaikka absoluuttinen objektiivisuus eli "näkökulma ei-mistään" on loogisesti ja käytännöllisesti mahdotonta saavuttaa, journalisti voi omaksua objektiivisen asenteen ja pyrkiä sulkeistamaan tilapäisesti ennakkoluulonsa tutkimusprosessin ajaksi. Yksittäinen tiedonhankkija voi näin sisällyttää näkökulmaansa myös muita näkökulmia ja tavoitellun tiedon kohteen relevantteine suhteineen muihin kohteisiin objektiivisen asenteen ansiosta. (Lehtinen 2019; 2016; ks. Ward 2010a; 2004, 281-288; ks. myös Haskell 1998; Nagel 1986.)

Pragmatistiseen tietokäsitykseen sopii myös objektiivisuuden ymmärtäminen itseäänkorjaavana tiedonhankintamenetelmänä (Lehtinen 2016; Megill 1994; Ward 2004; ks. Bernstein 2010, 111; vrt. Niiniluoto 2002, 148-150). Pragmatistista tutkimusta eli tiedon hankkimisen prosessia ohjaavat Journalistin ohjeiden ja uutiskriteerien kaltaiset normit, joita ei kuitenkaan inhimillisinä sääntöinä pidä käsittää dogmaattisina vaan kokemuksen myötä kehitettävinä, korjattavina ja tarkennettavina ohjenuorina tiedon tiellä. Yleisöjen luottamusta lisännee, että nämä normit artikuloidaan avoimesti yleisöille samoin kuin tiedonhankinnan prosessin eri vaiheet (ks. Kuutti 2015). Journalisti voi esimerkiksi tuoda jutussaan tai sen yhteydessä julki tietolähteet sidoksineen sekä käyttämänsä tulkinnalliset perusteet. Faktuaalinen todistusaineisto ei ehkä aina puhu puolestaan, vaan sen käyttöä pitää perustella. Tällöin luottamusta herättävintä on vedota juuri journalistisen menetelmän objektiivisuuteen.

Pragmaattiseen objektiivisuuteen kuuluvat siis sekä asenne että menetelmä (Ward 2004). Normien ohjaamaan menetelmään puolestaan kuuluvat muun muassa aiheen valinta ja rajaus sekä aihepiirin kartoitus informatiivisimpien ja luotettavimpien lähteiden kartoittamiseksi. Erilaisista lähteistä kerätyn aineiston paikkansapitävyyttä testataan kriittisellä arvioinnilla ja saatavilla olevan todistusaineiston valossa. Sitten tulee olennaisen tulkinnan vuoro, koska kaikkea todennettuakaan tietoa ei ole mielekästä julkaista sellaisenaan ilman asiayhteyksien osoittamista ja epäolennaisuuksien karsimista. Tulkinnan ohjenuorana voi toimia esimerkiksi uutisessa sen perinteinen käänteisen pyramidin malli, jossa yleisöille selvitetään, kuka teki mitä missä ja miksi ja milloin. Valitun aiheen käsittelyssä keskeistä on tietojen paikkansapitävyyden lisäksi niiden tarkkuus ja kontekstualisointi. Ei ole kuitenkaan yhdentekevää, mitä yksityiskohtia pitää tarkentaa. Kattavaan journalistiseen juttuun kuuluu myös raportoitavan tapahtuman tai ilmiön mahdolliset seuraukset sekä jatkuva valmius vastaanottaa kritiikkiä ja korjata mahdolliset virheet. Pragmatistisen tietokäsityksen ytimessä on falli- 
bilismi eli tietoväitteiden potentiaalinen erheellisyys. Pragmaattisen objektiivisuuden harjoittaminen on prosessi, joka ei lopu julkaisuun. (Lehtinen 2016; 2013; Kuutti 2015.)

Filosofisesti ja journalismin käytännön kannalta on tärkeää muistaa, että todellisuus ei ole valmiiksi jakautunut tosiasioiden muotoisiin osatekijöihin tai tarkkarajaisiin tapahtumiin. Tiedollisesti ja eettisesti perusteltu tulkinta on siksi keskeisin osa journalistista prosessia. Esimerkiksi suoria silminnäkijätodistuksia pidetään liian helposti luotettavina, vaikka useat sosiaalipsykologiset ja psykologiset kokeet ovat osoittaneet, että yhden ja saman tapahtuman paikan päällä reaaliajassa todistaneet inmiset antavat siitä keskenään ristiriitaisia lausuntoja (ks. esim. Psychology 2020). Journalistinen lähdekritiikki ei siis riitä, jos se kohdistuu vain todistajan tai todistusaineiston antajan henkilöön tai asemaan. Kriittisyys ja kumottaviksi tarkoitetut vastaväitteet ovat vain apuvälineitä sen selvittämiseksi, mitä tapahtui todella. Journalistisen menetelmän tulee siksi pureutua vielä lähdekritiikinkin tuolle puolen suoraan todellisuudesta tai todistusaineistosta saatavan aineiston koettelemiseen, koska vasta todellisuus asettaa tulkinnalle reunaehdot.

Pragmaattinen objektiivisuus on filosofinen väline, jonka edelleen kehittäminen voi auttaa journalismia ja sen empiiristäkin tutkimusta rajaamaan journalismia itsenäisenä käytäntönä (ks. esim. Reunanen \& Koljonen 2015). Totuudenmukaisuuden tavoittelussa huomio keskittyy abstraktin tiedon sijasta konkreettiseen tiedonhankintamenetelmään faktantarkistuksineen ja toimituksellisine käytäntöineen, jotka kaikki yhdessä tukevat tiedonhankinnan prosessin luotettavuutta. Tämä luotettavuus voidaan heijastaa yleisöjen luottamukseksi journalistista tietoa kohtaan, kun menetelmä selitetään läpinäkyvästi auki muillekin kuin journalisteille ja journalismin tutkijoille. Filosofian käsitteellisten kehitelmien artikuloiminen yleisymmärrettävästi ei ole helppoa edes käytäntöä painottavan pragmatismin osalta, mutta mahdollista se silti on.

Se on myös toivottavaa, sillä journalismille tarjoaa lisäarvoa pragmatismiin kuuluva käsitys meliorismi, jonka mukaan filosofialla tulisi olla yhteiskunnallisesti rakentavaa merkitystä ja vaikuttavuutta (Stuhr 2019). Varsinkin Dewey painotti filosofian roolia sosiaalisten olojen parantamisessa, jota elinvoimainen ja kehittyvä journalismi voivat tukea (Hildebrand 2013). Uusien käsitteellisten välineiden avulla journalismi ja sen tutkimus voivat tuottaa parempia tuloksia myös yhteiskunnan toimivuuden kannalta. Käsitteellisesti selvennetyt objektiivisuus ja totuudenmukaisuus voivat edistää laatujournalismin luottamussuhdetta yleisöjen kanssa.

\section{Journalismin totuudenmukaisuus}

Artikkelin perusargumentin mukaan Journalistin ohjeiden "totuudenmukainen tiedonvälitys" voi erottaa journalismin itsenäisenä tietokäytäntönä, kun totuudenmukaisuus saa ensin käsitteellisesti rikkaamman ja perustellun sisällön (8 §). Sen hankkimiseksi Journalistin ohjeissa on yleisiä käytännön normeja (9 § ja 14-16 §). Journalistin ohjeissa mainitaan totuudenmukaisuutta seuraavissa pykälissä muun muassa tietojen tarkistaminen (10 §), tosiasioiden erottaminen mielipiteistä ( $(11)$ ja kriittisyys tieto- 
lähteitä kohtaan (12 §), jotka kuuluvat sellaisinaan myös pragmatistiseen käsitykseen tiedonhankinnasta. Tosiasiallisen uutisen saa julkaista tarvittaessa "keskeneräisenä", koska pragmatistiseen tietokäsitykseen kuuluu olennaisesti tiedon prosessuaalisuus ja itseäänkorjaavuus ( $13 \S$ ). Tosiasia eli fakta on kuitenkin totuudenmukaisuuden tavoin selvennystä vaativa käsite, sillä tietoteoreettisesta näkökulmasta tosiasioiden rajaaminen, todentaminen ja esittäminen asettavat haasteita. Pragmatistisen tietokäsityksen varassa myös niihin voidaan tarjota käsitteellistä selkeyttä.

Pysyvä syy journalismin luotettavuuden epäilyksenalaisuudelle on se, että tiedonvälitys tarjoaa yleisöille niin sanottua toisen käden tietoa: journalismiin on pystyttävä luottamaan, koska tieto saadaan oletettavasti tietäväisiltä journalisteilta. Journalistinen tieto todellisuudesta on kirjaimellisesti välittynyttä, koska journalismin tarjoama tieto ei ole yleisöille omakohtaista kokemuksellista tietoa. (Farkas \& Schou 2018.) Mutta välittynyttä on myös sosiaalisen median ja internetin harhaanjohtava valeuutisointi ja muu disinformaatio, joka levitessään heikentää yleisöjen luottamusta kaikkeen välitettyyn tietoon. Huoli luottamuksen heikentymisestä disinformaation takia on aiheellinen, koska disinformaatio leviää käyttäjältä toiselle nopeammin ja laajemmin kuin tiedollisesti luotettava informaatio (Allcott \& Gentzkow 2017, 215; Vosoughi ym. 2018). Journalismin tulee erottautua itsenäisenä tietokäytäntönä, jotta ero journalismin ja julkaisualustojen välillä sekä käsitys journalistisesta tiedosta säilyvät. Tässä artikkelissa ehdotetaan pragmatismin hengessä totuudenmukaisuuden käsitteen selventämistä ja rikastuttamista älylliseksi ja käytännölliseksi työkaluksi, jonka avulla voidaan tukea journalismin tiedollis-eettistä autonomiaa ja siten rajata journalismin tutkimukselle kohde.

Kaiken kommunikatiivisen toiminnan taustaoletus on, että elämme objektiivisesti olemassa olevassa maailmassa, josta voidaan esittää totuudenmukaisia ja harhaanjohtavia väitteitä (ks. Putnam 1990; Pihlström 1996; Rescher 1999). Walter Lippmannin mukaan "totuuden tehtävä on tuoda esiin piilossa olevat tosiasiat, suhteuttaa ne toisiinsa ja luoda sellainen kuva maailmasta, että sen perusteella ihmiset voivat toimia" (Lippmann 1922, 358; Deweyn ja Lippmannin suhteesta ks. Allan 2010). Yksittäiset totuudet tai tosiasiat eivät kuitenkaan puhu puolestaan tai luo kuvaa todellisuudesta ilman journalistin tai journalistiyhteisön tiedollista toimintaa, aktiivista tutkimusta (Maras 2013, 82-103; ks. Kuutti 2015, 27-31). Siksi tarvitaan laajempaa totuudenmukaisuuden käsitettä, jonka sisältämään itsekriittisyyteen kuuluu journalistinen avoimuus kertoa tiedetyn piiriin kuuluvien asioiden lisäksi se, mitä ollaan vasta tutkimassa. Myös epätietoisuuden tunnistaminen on tietoa. (Ks. Jones 2009, 88; Williams 2002, 19.)

Journalismi professiona on muuttunut koko lyhyen historiansa ajan, ja siten ovat muuttuneet myös sen käytännöistä kumpuavat käsitteet (Pettegree 2014; Pietilä 2012). Uusia ongelmia journalismille itsenäisenä ja luotettavana tietokäytäntönä tuottaa digitaalisesti leviävä disinformaatio. Ensimmäinen haaste totuudenmukaisuudelle on tällöin filosofisesti ottaen käsitejärjestelmien moneus. Maailmassa puhutaan tuhansia eri kieliä, ja todellisuutta voidaan jäsentää kokemuksessa monenlaisin erilaisin käsitteellisin, moraalisin ja ideologisin tavoin (Lehtinen 2016, 153-158; 2013; ks. Dewey 2006; Fesmire 2019; Freeden 2019). Kuinka siis voidaan arvioida, mitkä erot 
johtuvat disinformaatiosta ja mitkä erilaisista käsitteellistämisen tavoista? Totuudenmukaisuuden käsite voidaan pragmatistisista lähtökohdista hahmotella journalismin yleispäteväksi tavoitteeksi, kun käsitettä taustoittavat käytännöllinen käsitys objektiivisuudesta tiedonhankintamenetelmänä sekä riittävän yhtäläiset eettiset normit (globaalista journalismietiikasta ks. Ward 2010b).

Journalistinen totuudenmukaisuus toteutuu, kun journalisti myös tulkitsee valittujen, rajattujen ja varmennettujen tosiasioiden varassa kirjoittamansa jutun. Kuten edellä on todettu, tulkinta kuuluu objektiivisen tiedonhankintamenetelmään. Todellisten tapahtumien ja ilmiöiden totuudenmukainen tulkinta voidaan ymmärtää pragmatistisesti asteittaisena eli prosessiluonteisena toimintana. Journalistinen tulkinta yhdistää rationaalisesti todistusaineiston väitteisiin ja liittää tosiasiat toisiinsa noudattamalla todellisuuden tapahtumien kausaalisia kytköksiä (ks. Hildebrand 2019, 103). Kaikkea ei kuitenkaan tarvitse kertoa, koska syy-seuraussuhteiden tai psykologisten motiivien ketjuja voisi periaatteessa jatkaa loputtomasti. Se ei ole mielekästä eikä mahdollista. Esimerkiksi syyskuun 11. päivän 2001 terrori-iskuissa World Trade Centerin kahteen torniin lennettiin lentokoneilla, mikä kausaalisesti aiheutti tornien syttymisen tuleen ja romahtamisen. Näistä välittömistä syistä raportoitiin journalistisesti ennen kuin selvisi tarkemmin, ketkä olivat tekojen taustalla ja minkälaisilla motiiveilla. Iskuissa kuoli tuhansia ihmisiä ja poliittisesti ne johtivat sotaan sekä maailmanpolitiikan ja ideologisten rajanvetojen uudelleenmuotoutumiseen. Näitä asioita käsiteltiin journalismissa myöhemmin tapahtumien edetessä, todistusaineiston lisääntyessä ja analyysien tarkentuessa. On journalistisen tulkinnan varassa, miten sittemmin tapahtuneet terrori-iskut, sotatoimet, pakolaisvirrat ja niiden yhteiskunnalliset vaikutukset ymmärretään ja selitetään yleisöille.

Totuudenmukaiseen tulkintaan kuuluu parhaiden perustelujen arviointi lukuisten selitysten joukosta sekä olennaisen erottaminen epäolennaisesta (Hacking 2009, 22; Ward 1998, 122). "Terrorismin vastainen sota" on jatkunut nykyisyyteen saakka, mutta kaikissa uutisissa ei ole olennaista palauttaa raportoituja tapahtumia vuoteen 2001 tai sitä edeltäviin tapahtumiin. Olennaisen valitsemisesta eli tulkinnasta kertoo myös esimerkiksi Wikileaks-sivusto, joka paljasti salaiseksi luokiteltua informaatiota sellaisenaan ilman journalistista tulkintaa, mutta pääsääntöisesti yhteistyössä journalististen julkaisijoiden eli "tulkitsijoiden" kanssa yhteistyössä. Kuten edellä on todettu, kaikkea ei voida inhimillisissä rajoissa kertoa, eikä siitä olisi tiedollista hyötyäkään. On lisäksi kiistanalaisia tapauksia, joissa sananvapaus on ristiriidassa yksilönsuojan tai yleisen turvallisuuden kanssa (ks. Tiilikka 2008; 2007). Tällöin totuudenmukaisuudelle pitää olla erityisen vahvoja perusteita. Esimerkiksi Wikileaksin haltuunsa saamat diplomaattisähkeet olisivat voineet asettaa sellaisinaan julkaistuina ihmisiä hengenvaaraan. Totuudenmukaisuus ja objektiivisuus ovat normien ohjaamaa toimintaa.

Kun tapahtuma tai ilmiö on rajattu journalistisesti tulkiten, etsitään ja todennetaan juuri kyseisessä journalistisessa tuotteessa olennaiset faktat, jotka tulee vielä tarkistaa ja perustella evidenssin avulla totuuksiksi. Tulkintaprosessi edellyttää, että tosiasiat eli "totuudet" suhteutetaan toisiinsa ja kontekstualisoidaan perustelluilla argumenteilla. Totuudenmukaisuus toimii näin myös journalistisen jutun arviointikriteeristönä, joka 
voidaan jakaa totuudenmukaisuuden eri asteisiin (ks. Achourioti ym. 2015; Niiniluoto 2019; Raynaud 2019).

Ensimmäisenä asteena voidaan pitää tiedon hankkimisen objektiivisuuden arviointia (ks. objektiivisuudesta edellä). Tämä vaihe koskee journalistisen käytännön, sen avulla saadun aineiston, sen todentamisen ja esittämisen arviointia. Kun tiedonhankinnan menetelmällä on pragmaattisen objektiivisuuden kaltaiset selkeät ja käytännössä testatut ohjeet ja niiden noudattamista valvotaan toimituksessa, päästään lähemmäksi potentiaalisesti totuudenmukaista journalistista juttua, tosiasioista koostuvaa koherenttia totuudenmukaista kokonaisuutta. (Goldsmith 2017; Maras 2013, 97; Schudson 1978, 120.)

Totuudenmukaisuuden toinen aste on tarkistaa, että tietolähteitä on riittävästi ja että ne ovat luotettavia - olivat sitten kyseessä ihmiset tai dokumentit. Mahdollisimman tasapuolinen sekä puolueeton lähteiden kuuleminen, lukeminen ja tutkiminen ovat tärkeä osa tiedonhankintaa, mutta ne eivät voi olla totuudenmukaisuutta tavoittelevan tiedonhankinnan päämäärä. Kuten jo on todettu, aineistoksi kertyy enemmän ja vähemmän paikkansapitäviä lausuntoja ja dokumentteja, eikä journalisti voi olla puolueeton totuudenpuhumisen ja valheen välillä (Graves 2016). Koko totuuden tai totuudenmukaisuuden käsite on mielekäs vain suhteessa vastinpariinsa eli valehtelemiseen tai harhaanjohtamiseen, ja esimerkiksi valeuutinen on mielekäs termi vain suhteessa totuudenmukaiseen uutiseen (Vihma ym. 2018, 229-230; ks. Dewey LW 12, 16; Hildebrand 2008, 59-60). Esimerkiksi disinformaatiota ei voi sellaiseksi paljastaa ilman jonkinlaista käsitystä totuudenpuhumisesta (Haasio ym. 2018; McChesney 2000, 305-307; 2003; Schetzer 2019). Faktantarkistus eli tosiasioiden totuuden varmistus koskee yksittäisiä väittämiä ja tosiasiaoletuksia (ks. Sankari \& Wiberg 2019, $236,243)$. Se kuuluu olennaisena osana objektiiviseen tiedonhankintamenetelmään, jossa faktat eli tosiasiat asetetaan arvioitaviksi kontekstissaan. Jos yksittäisistä faktoista ei päästä evidenssin varassa yhteisymmärrykseen, ei ole myöskään mahdollista vetää totuudenmukaisia tulkinnallisia johtopäätöksiä ja tehdä totuudenmukaisia toimituksellisia päätöksiä (Lynch 2016, 61-63; 2004; 1998). Prosessien on siis oltava luotettavia.

Kolmanneksi totuudenmukaisuus edellyttää yhteisöllistä ja itsekriittistä journalistista toimintaa, jossa toimittajan ja faktantarkistajan lisäksi juttu oikoluetaan sen kielellisen virheettömyyden ja koherenssin varmistamiseksi. Vaiheen tarkoitus on karsia jutusta pois sen mahdolliset sisäiset ristiriitaisuudet, jollei sellaisia ole itse raportoitavassa tapahtumassa tai ilmiössä. Muita tiedollisia heikkouksia voidaan poistaa vertaamalla tekstiä muuhun perustellusti tiedettyyn sekä journalistisiin kriteereihin (Calcutt \& Hammond 2011, 98; ks. Baggini 2002, 17; Goldstein 2007, 70).

Totuudenmukaisuuden neljännessä vaiheessa tulkinnallisuus tarkoittaa jutun kokonaiskontekstina olevan maailman jäsentämistä kielellis-käsitteellisesti suhteessa todellisuudesta saatavaan ja testattuun todistusaineistoon (Newell 1986, 105-106). Journalistin pitää siis tunnistaa ja tunnustaa oma tapansa jäsentää ja käsitteellistää todellisuutta, josta hän tai journalistiyhteisö tavoittelee tiedollis-eettiset kriteerit täyttävää tietoa (Ward 2004, 300). 
Viidenneksi totuudenmukaisuuden asteeksi asettuu yleisön taustatieto ja ennakkokäsitykset, jotka vaikuttavat journalistisen viestin vastaanottamiseen. Ne on huomioitava, jotta jutun muotoilu ja tyyli tukisivat totuudenmukaisuuden välittämistä ja nousisivat kiinnostavuuden rinnalle keskeiseen asemaan yleisön huomion kohteena. Journalistikaan ei ole vapaa subjektiivisista ja kulttuurisidonnaisista ennakkoluuloista ja -oletuksista, mutta objektiivisella asenteella ja menetelmällä hän voi pyrkiä totuudenmukaiseen tietoon, jonka voi esittää yleisöjen huomion ansaitsevalla ja saavalla tavalla. Viidenteen asteeseen kuuluu lisäksi korjausehdotusten ja kommenttien vastaanottaminen yleisöltä, mutta vuoropuhelu yleisöjen kanssa tulee käydä journalismin autonomia säilyttäen (Journalistin ohjeet 2 ja 3 §).

\section{Yleisöt ja luottamussopimus}

Pragmatistisen menetelmän ja selkeytettyjen käsitteiden avulla voidaan osoittaa yleisöille, että jotkut todellisuutta koskevat väitteet ovat kiistattomia ja siksi luotettavia, kun taas toiset väitteet eivät ole ainakaan toistaiseksi uskottavia vajavaisen todistusaineiston tai heikkojen perustelujen takia (Dewey MW 2, 313-314; LW 14, 45). Luottamusta lisännee, että tietojen epävarmuudesta ollaan avoimia ja tehdyt virheet paljastetaan ja korjataan. Rehellisyys on arvo myös arkikommunikaatiossa, jossa se niin ikään herättää luottamusta. Tällainen menetelmään ja käsitteisiin tarkentuva täsmennys myös tarjoaisi journalismin tutkimukselle selkeärajaisen kohteen, jollaista on peräänkuulutettu journalismin tutkimuksen sisälläkin (Rupar 2010).

Pragmatistisesti hahmotellussa journalismin tulkintaprosessissa vältetään epätosia uskomuksia ja väitteitä, kontekstualisoidaan tosiasiat tapahtuman tai ilmiön suhdeverkostoon ja kootaan yhteen journalistinen tuotos juttutyypin ja journalistisen alustan määrittelemissä rajoissa (Merrill 1997, 115). Journalistiset kannanotot (pääkirjoitukset, kolumnit ja blogit) voidaan erottaa faktuaalisista uutisista ilmoittamalla kulloinkin kyseessä oleva journalismin genre.

Journalismin tärkeimpiin tehtäviin kuuluu totuudenmukaisen ja siksi luotettavan tiedon tarjoaminen kansalaisille poliittisista, kulttuurisista ja taloudellisista tapahtumista ja muutoksista yhteiskunnassa (Journalistin ohjeet 1 §). Julkisen keskustelun ylläpitäminen ja kehittäminen ovat liberaalin demokratian ylläpitämistä ja kehittämistä. Keskustelu kaipaa tiedollisesti ja eettisesti kestävän lähtökohdan ja viitekehyksen, jotka journalismi voi tarjota (Tandoc ym. 2018). Tämä kuitenkin edellyttää luottamusta, joka perustuu journalistisen tiedon totuudenmukaisuuteen. Luottamus myös vaatii sen, että kaikki osapuolet ymmärtävät, mitä totuudenmukaisuudella tarkoitetaan (Hatford 2019). Tosiasioihin pohjautuva julkinen keskustelu suorastaan edellyttää journalistista totuudenmukaisuutta (Benkler ym. 2017). Näistä syistä journalistiset menetelmät ja käsitteet olisi suotavaa avata myös yleisöille - journalistien ammatillisen itseymmärryksen ja journalismin tutkimuksen tukemisen lisäksi. Avoimesti artikuloitu totuudenmukaisuus voisi toimia luottamussopimuksena journalismin ja sen yleisöjen välillä, kun käsitteen sisältö on selvitetty journalismissa ja sen tutkimuksessa. 
Kuten alussa todettiin, journalismilta puuttuu yhteiskunnassa oma filosofiansa oppiaineena. Journalistinen totuudenmukaisuus ei silti ole jäänyt "totuudenjälkeisen ajan", "valeuutisten", "vaihtoehtoisten faktojen" tai muun disinformaation varjoon (D'Ancona 2017). On vaikea kuvitella, miten ihmiskunta olisi selvinnyt nykyisyyteen asti pelkästään epätosien uskomusten ja valheiden varassa. Yhteisö (community) edellyttää hyödyllistä viestintää (communication), ja totuudenmukainen viestintä lienee yhteisölle kaikkein hedelmällisintä. Vähintäänkin se on hyödyllistä luottamuksen rakentamisessa ja ylläpitämisessä. Siksi journalismin on ansaittava yleisöjensä luottamus totuudenmukaisuudella, jota voisi käsitteenä avata toimituksissa ja jopa Journalistin ohjeiden liitteissä.

Journalismin ja yleisöjen välisenä luottamussopimuksena totuudenmukaisuutta voitaisiin tutkia globaalina journalistisena ohjenuorana, koska tieto ja muu informaatio ylittävät digitaalisena aikakautena maantieteelliset ja usein kielellisetkin rajat. (Sambrook 2018; Ward 2010b.) Tässä artikkelissa on vasta hahmoteltu totuudenmukaisuutta pragmatistisen tietokäsityksen varassa siinä toivossa, että keskustelu totuudenmukaisuudesta sekä journalismin tiedollisesta identiteetistä voisi jatkua journalismissa ja sen tutkimuksessa. Uudelleenmuotoillut ja selvennetyt käsitteet objektiivisuus ja totuudenmukaisuus voitaisiin näin ottaa takaisin työkaluina journalismin ja sen tutkimuksen käsitteelliseen pakkiin.

\section{Kirjallisuus}

Achourioti, Theodora; Galinon, Henri; Martìnez Fernández, José \& Fujimoto, Kentaro (toim.) (2015). Unifying the Philosophy of Truth (Logic, Epistemology, and the Unity of Science). Dordrecht: Springer. https://doi.org/10.1007/978-94-017-9673-6

Allan, Stuart (2010). Journalism and Its Public: The Lippmann-Dewey Debate. Teoksessa Allan, Stuart (toim.). The Routledge Companion to News and Journalism. Oxon \& New York: Routledge, 60-70.

Allcott, Hunt \& Gentzkow, Matthew (2017). Social Media and Fake News in the 2016 Election. Journal of Economic Perspectives 31:2, 221-236. https://doi.org/10.3386/w23089

Appelqvist, Hanne (2010). Representaatio ja sen rajat Wittgensteinin filosofiassa. Teoksessa: Knuuttila, Tarja \& Lehtinen, Aki Petteri (toim.). Representaatio: tiedon kivijalasta tieteiden työkaluksi. Helsinki: Gaudeamus, 54-74.

Baggini, Julian (2003). The Philosophy of Journalism. OpenDemocracy. Saatavilla: www.opendemocracy.net/ media-journalismwar/article_1218.jsp (luettu 8.9.2020).

Baggini, Julian (2002). Making Sense: Philosophy Behind Headlines. Oxford: Oxford University Press.

Benkler, Yochai; Faris, Robert; Robers, Hal \& Zuckerman, Ethan (2017). Study: Breitbart-led right wing media ecosystem altered broader media agenda. Columbia Journalism Review 3.3.2017. Saatavilla: https://cjr. org/analysis/breitbart-media-trump-harvard-study.php (luettu 8.9.2020).

Bernstein, Richard J. (2010). The Pragmatic Turn. Cambridge: Polity Press.

Boghossian, Paul (2006). Fear of Knowledge: Against Relativism and Constructivism. Oxford: Clarendon Press. https://doi.org/10.1093/acprof:oso/9780199287185.001.0001

Boudana, Sandrine (2015). Impartiality is not fair: Toward an alternative approach to the evaluation of content bias in news stories. Journalism 17:5, 1-19. https://doi.org/10.1177/1464884915571295

Calcutt, Andrew \& Hammond, Philip (2011). Journalism Studies: A Critical Introduction. London: Routledge. https://doi.org/10.4324/9780203831748

Cooke, Nicole A. (2017). Posttruth, truthiness, and alternative facts: Information behavior and critical information consumption for a new age. The Library Quarterly 87:3, 211-221. https://doi.org/10.1086/692298 
D'Ancona, Matthew (2017). Post Truth: The New War on Truth and How to Fight Back. London: Ebury. Dewey, John (2012 [1919]). Filosofian uudistaminen. Suomentanut Tuukka Perhoniemi. Tampere: Vastapaino.

Dewey, John (2006 [1927]). Julkinen toiminta ja sen ongelmat. Suomentanut Mika Renvall. Tampere: Vastapaino.

Dewey, John (1999 [1929]). Pyrkimys varmuuteen: tutkimus tiedon ja toiminnan suhteesta. Suomentanut Pentti Määttänen. Helsinki: Gaudeamus.

Dewey, John (1958). Experience and Nature. New York: Dover Publications.

Dewey, John (1925-1853). LW 14 = The Later Works. 17 Volumes, Carbondale: Southern Illinois University Press.

Dewey, John (1925-1953). LW 12 = The Later Works. 17 Volumes. Carbondale: Southern Illinois University Press.

Dewey, John (1899-1924). MW 2 = The Middle Works. 15 Volumes. Carbondale: Southern Illinois University Press.

Edelman (2020/ 2019 / 2018 / 2017). Trust Barometer. Saatavilla: www.edelman.com/trustbarometer (luettu 8.9.2020).

EU (2019). Eurobarometer PublicOpinion. Saatavilla: https://ec.europa.eu/commfrontoffice/ publicopinionmobile/index.cfm/General/index (luettu 8.9.2020).

Farkas, Johan \& Schou, Jannick (2018). Fake News as a Floating Signifier: Hegemony, Antagonism and the Politics of Falsehood. Javnost - The Public 25:3, 298-314. https://doi.org/10.1080/13183222.2018.1463047

Fesmire, Steven (2019). Beyond moral fundamentalism: Dewey's pragmatic pluralism in ethics and politics. Teoksessa: Fesmire, Steven (toim.). The Oxford Handbook of Dewey. Oxford: Oxford University Press, 209-234. https://doi.org/10.1093/oxfordhb/9780190491192.013.38

Figdor, Carrie (2010). Is bjective news possible? Teoksessa: Meyers, Christopher (toim.). Journalism Ethics: A Philosophical Approach. Oxford: Oxford University Press, 153-165. https://doi.org/10.1093/acprof:0so/9780195370805.003.0010

Freeden, Michael (2019 [2003]). Mitä on ideologia? Suomentanut Tapani Kilpeläinen. Tampere: niin \& näin.

Godfrey-Smith, Peter (2019). Dewey and anti-representationalism. Teoksessa: Fesmire, Steven (toim.). The Oxford Handbook of Dewey. Oxford: Oxford University Press, 151-171. https://doi.org/10.1093/oxfordhb/9780190491192.013.4

Goldsmith, Belinda (2017). Trust the news? Most people don't, social media even more suspect - a study. Saatavilla: https://www.reuters.com/article/us-media-news-survey/trust-the-news-most-people-dontsocial-media-even-more-suspect-study-idUSKBN19Do15 (luettu 8.9.2020).

Goldstein, Tom (2007). Journalism and Truth: Strange Bedfellows. Evanston, IL: North-Western University Press.

Graves, Lucas (2016). Deciding What's True: The Rise of Political Fact-Checking in American Journalism. New York: Columbia University Press. https://doi.org/10.7312/grav17506

Haasio, Ari; Ojaranta, Anu \& Mattila, Markku (2018). Valheen jäljillä. Vantaa: Avain / BTJ Finland.

Hacking, Ian (2009[1999]). Mitä sosiaalinen konstruktionismi on? Suomentanut Inkeri Koskinen. Tampere: Vastapaino.

Haskell, Thomas L. (1998). Objectivity Is Not Neutrality: Explanatory Schemes in History. Baltimore: The Johns Hopkins University Press.

Hatford, Tim (2019). Why there is no need to panic about fake news. Financial Times 4.1.2019. Saatavilla: https://www.ft.com/content/2c962eea-050c-11e9-9do1-cd4d49afbbe3 (luettu 8.9.2020).

Hautakangas, Mikko \& Ahva, Laura (2018). Sovittelujournalismi kirkastaa keskustelua. Teoksessa: Niemi, Mari K. \& Houni, Topi (toim.). Media Q populismi: työkaluja kriittiseen journalismiin. Tampere: Vastapaino, 278-303.

Hemánus, Pertti (1995). Opettaako journalismia Siperia vai tieto-oppi. Teoksessa: Sana, Elina (toim.). Tietoopista mediapeliin - journalismin tutkimuksen näkökulmia. Helsinki: WSOY, 27-46.

Hemànus, Pertti \& Tervonen, Ilkka (1980). Objektiivinen joukkotiedotus. Helsinki: Otava.

Hildebrand, David (2019). Dewey, Rorty, and Brandom: The challenges of linguistic neopragmatism. Teoksessa: Fesmire, Steven (toim.). The Oxford Handbook of Dewey. Oxford: Oxford University Press, 99-130. https://doi.org/10.1093/oxfordhb/9780190491192.013.5

Hildebrand, David (2013). Dewey's pragmatism: Instrumentalism and meliorism. Teoksessa: Malachowski, Alan (toim.). The Cambridge Companion to Pragmatism. Cambridge University Press, 55-80. https://doi.org/10.1017/CCO9781139022132.006 
Hildebrand, David (2011). Pragmatic objectivity in history, journalism and philosophy. Southwest Philosophy Review 27:1, 1-20. https://doi.org/10.5840/swphilreview20112711

Hildebrand, David L. (2008). Dewey: A Beginner's Guide. Oxford: Oneworld Publications.

Hildebrand, David L. (2003). Beyond Realism and Anti-Realism: John Dewey and the Neopragmatists. Nashville, TN: Vanderbilt University Press.

Hopf, Henning; Krief, Alain; Mehta, Goverdhan \& Matlin, Stephen A. (2019). Fake science and the knowledge crisis: Ignorance can be fatal. Royal Society Open Science 6. https://dx.doi.org/10.1098/ rsos.190161

Hutchinson, Phil \& Read, Rupert (2013). Practicing pragmatist-Wittgensteinianism. Teoksessa: Malachowski, Alan (toim.). The Cambridge Companion to Pragmatism. Cambridge University Press, 159-188. https://doi.org/10.1017/CCO9781139022132.011

James, William (2008[1907]). Pragmatismi: uusi nimi eräille vanhoille ajattelutavoille. Suomentanut Antti Immonen. Tampere: Eurooppalaisen filosofian seura / niin \& näin -kirjat.

Jones, Alex S. (2009). Losing the News: The Future of the News That Feeds Democracy. Oxford: Oxford University Press.

Journalistin ohjeet (2014). Julkisen sanan neuvosto. Saatavilla: https://www.jsn.fi/journalistin_ohjeet/ (luettu 8.9.2020).

Karppinen, Kari; Jääsaari, Johanna \& Kivikuru, Ullamaija (2010). Media ja valta kansalaisten silmissä. Helsinki: Svenska social- och kommunalhögskolan vid Helsingfors universitet.

Kilpinen, Erkki; Kivinen, Osmo \& Pihlström, Sami (toim.) (2008a). Pragmatismi filosofiassa ja yhteiskuntatieteissä. Helsinki: Gaudeamus.

Knuuttila, Tarja \& Lehtinen, Aki Petteri (2010). Representaatio - tiedon kivijalasta tieteiden työkaluksi. Teoksessa: Knuuttila, Tarja \& Lehtinen, Aki Petteri (toim.). Representaatio. Helsinki: Gaudeamus, 7-34.

Kovach, Bill \& Rosenstiel, Tom (2007). The Elements of Journalism. What Newspeople Should Know and the Public Should Expect. Revised edition. New York: Three Rivers Press.

Kunelius, Risto (2003). Viestinnän vallassa: johdatusta joukkoviestinnän kysymyksiin. Helsinki: WSOY.

Kuutti, Heikki (toim.) (2015). Todenmukainen journalismi. Jyväskylän yliopisto.

Lehtinen, Aki Petteri (2019). Sisältöä totuudenmukaisuudelle. Tieteessä tapahtuu 2, 17-22.

Lehtinen, Aki Petteri (2016). Journalismin objektiivisuus: pragmaattinen tietokäsitys ja relativismin haaste moniarvoisessa maailmassa. Helsingin yliopisto: Sosiaalitieteiden laitos. Saatavilla: https://helda.helsinki.fi/handle/10138/161455 (luettu 8.9.2020).

Lehtinen Aki Petteri (2015). Vapaus sanaan - ja vastuu sanoista. Kaltio 5, 13-17. Saatavilla: https://www.kaltio.fi/lehtiarkisto/kaltio-5-2015/lehtinen515 (luettu 8.9.2020).

Lehtinen, Aki Petteri (2013). Objektiivisuus 2.0: muslimien raivo ja journalistinen tieto. Teoksessa: Kurvinen, Heidi (toim.). Journalismikritiikin vuosikirja 2012. Tampere: Journalismin tutkimusyksikkö COMET.

Lichtenberg, Judith (2000). In defense of objectivity revisited. Teoksessa: Curran, James \& Gurevitch, Michael (toim.). Mass Media and Society. London: Arnold, 238-254.

Lippmann, Walter (1922). Public Opinion. New York: Free Press.

Luostarinen, Heikki \& Raittila, Pentti (2014) (toim.). Journalistin vapaus. Tampere: Vastapaino.

Lynch, Michael P. (2016). The Internet of Us: Knowing More and Understanding Less in the Age of Big Data. Cambridge: MIT Press.

Lynch, Michael P. (2004). True to Life: Why Truth Matters. Cambridge, MA: MIT Press. https://doi.org/10.7551/mitpress/6919.001.0001

Lynch, Michael P. (1998). Truth in Context. An Essay on Pluralism and Objectivity. Cambridge, MA: The MIT Press. https://doi.org/10.7551/mitpress/6926.001.0001

Malmberg, Tarmo (2017). Totuus totuuden jälkeisenä aikana - mediatutkimuksen tieteenfilosofiaa. Media Q viestintä 40:3-4, 54-75. https://doi.org/10.23983/mv.67794

Maras, Steven (2013). Objectivity in Journalism. Key Concepts in Journalism. Cambridge: Polity Press.

Martevo, Essi (2019). Faktojen puolella: Toimittajien näkemyksiä faktantarkistuksesta. Pro gradu-tutkielma, Helsingin yliopisto. Saatavilla: https://hdl.handle.net/10138/301043 (luettu 8.9.2020).

McChesney, Robert W. (2003). The problem of journalism: A political economic contribution to an explanation of the crisis in contemporary U.S. journalism. Journalism Studies 4:3), 299-329. https://doi.org/10.1080/14616700306492 
McChesney, Robert W. (2000). Rich Media, Poor Democracy: Communication Politics in Dubious Times. Urbana: The University of Illinois Press.

McNair, Brian (2018). Fake News: Falsehood, Fabrication and Fantasy Journalism. Oxford: Routledge. https://doi.org/10.4324/9781315142036

Megill, Allan (1994). Introduction: Four senses of objectivity. Teoksessa: Megill, Allan (toim.). Rethinking Objectivity. Durham, NC: Duke University Press, 1-20.

Merrill, John (1997). Journalism Ethics: Philosophical Foundations for News Media. New York: St. Martin's Press.

Meyers, Christopher (2010). Ethics theory and decision-making. Teoksessa: Meyers, Christopher (toim.). Journalism Ethics: A Philosophical Approach. Oxford: Oxford University Press, 3-8.

MTV Uutisten mediakysely (kesäkuu 2014). Saatavilla: www.mtvuutiset.fi/yritys/yritysinfoartikkeli/mediakysely-yleiso-haluaa-tutkivaa-journalismia-mediapaattajat-uskovatsomeen/5112768\#gs.7kxo35 (luettu 8.9.2020).

Murphy, John P. (1990). Pragmatism: From Peirce to Davidson. Boulder, CO: Westview Press.

Mäntylä, Jorma (2008) (toim.). Journalistin etiikka. Helsinki: Gaudeamus.

Määttänen, Pentti (2009). Toiminta ja kokemus: pragmatistista terveen järjen filosofiaa. Helsinki: Gaudeamus.

Nagel, Thomas (1986). The View from Nowhere. New York: Oxford University Press.

Newell, R. W. (1986). Objectivity, Empiricism and Truth. Lontoo ja New York: Routledge \& Kegan Paul.

Niiniluoto, Ilkka (2019). Kuka hukkasi totuuden? Tieteessä tapahtuu 2 /2019, 9-15.

Niiniluoto, Ilkka (2002). Pragmatismi. Teoksessa: Niiniluoto, Ilkka \& Saarinen, Esa (toim.). Nykyajan filosofia. Helsinki: WSOY, 111-164.

Niiniluoto, Ilkka (1996[1989]). Informaatio, tieto ja yhteiskunta: filosofinen käsiteanalyysi. Helsinki: Edita.

Niiniluoto, Ilkka (1995). Todellisuus - onko sitä? Teoksessa: Sana, Elina (toim.). Tieto-opista mediapeliin: journalismin tutkimuksen näkökulmia. Helsinki: WSOY, 9-25.

O'Connor, Cailin \& Weatherall, James Owen (2019). The Misinformation Age. How False Beliefs Spread. New Haven: Yale University Press. https://doi.org/10.2307/j.ctv8jpohk

O'Donovan, Caroline (2014). Desire to learn more about the issue. Nieman Journalism Lab. June 2, 2014. Saatavilla: https://www.niemanlab.org/2014/o6/readers-like-stories-aboutproblems-more-whenthey-also-include-possible-solutions/ (luettu 8.9.2020).

Pettegree, Andrew (2014). The Invention of News: How the World Came to Know About Itself. New Haven: Yale University Press.

Pietilä, Kauko (2012). Journalismi ammattina: journalistiprofession teoria. Helsinki: Gaudeamus.

Pihlström, Sami (2002). Kokemuksen käytännölliset ehdot: kantilaisen filosofian uudelleenarviointia. Helsinki: Yliopistopaino.

Pihström, Sami (1996). Structuring the World: The Issue of Realism and the Nature of Ontological Problems in Classical and Contemporary Pragmatism. Acta Philosophica Fennica 59. Helsinki: The Philosophical Society of Finland.

Pihlström, Sami (1997). Tutkiiko tiede todellisuutta? Realismi ja pragmatismi nykyisessä tieteenfilosofiassa. Helsingin yliopisto: Filosofian laitos.

Powell, Alison (2019). The mediations of data. Teoksessa: Curran, James \& Hesmondhalgh, David (toim.). Media and Society. 6th Edition. New York: Bloomsbury Academic, 121-138.

Psychology (2020). Saatavilla: http://psychology.iresearchnet.com/social-psychology/social-cognition/ eyewitness-testimony-accuracy/ (luettu 8.9.2020).

Putnam, Hilary (1990). Realism with a Human Face. Cambridge, MA: Harvard University Press.

Pöyhtäri, Reeta; Väliverronen, Jari \& Ahva, Laura (2014). Mistä on suomalainen toimittaja tehty? Worlds of Journalism -surveyn tuloksia Suomesta. Tampereen yliopisto. Saatavilla: http://urn.fi/URN:ISBN:978-951-44-9506-9 (luettu 8.9.2020).

Quine, Willard. V. O. (1969). Ontological Relativity and Other Essays. New York: Columbia University Press. https://doi.org/10.7312/quing2204

Ramonet, Ignacio (2011). Mediaräjähdys: Journalismi hajonneen viestinnän aikakaudella. Helsinki: Into.

Raynaud, Dominique (2019). Truth in the post-truth era: Evaluating the theories of truth with a table of contingency. Teoksessa: Matthews, Michael R. (toim). Mario Bunge: A Centenary Festschrift. Springer Nature Switzerland AG 2019, 139-162. https://doi.org/10.1007/978-3-030-16673-1_8 
Rescher, Nicholas (1999). Realistic Pragmatism: An Introduction to Pragmatic Philosophy. Albany: SUNY Press.

Reuters (2019). Saatavilla: https://reutersinstitute.politics.ox.ac.uk/sites/default/files/2019-06/DNR_2019_FINAL_o.pdf (luettu 8.9.2020).

Reunanen, Esa \& Koljonen, Kari (2015). Toimittajan sanansijat. Tampere: Tampereen yliopistopaino.

Rolin, Kristina; Kakkuri-Knuuttila, Marja-Liisa \& Henttonen, Elina (2006). Johdanto: soveltava tutkimus ja tutkimuksen soveltaminen. Teoksessa: Rolin, Kristina; Kakkuri-Knuuttila, Marja-Liisa \& Henttonen, Elina (toim.). Soveltava yhteiskuntatiede ja filosofia. Helsinki, Gaudeamus, 7-15.

Rupar, Veronica (2010). Journalism and meaning-making: mapping the field of study. Teoksessa: Rupar, Veronica (toim.). Journalism and Meaning-Making: Reading the Newspaper. Cresskill, NJ: Hampton Press, 1-12.

Rusbridger, Alan (2018). Breaking News: The Remaking of Journalism and Why It Matters Now. Edinburgh: Canongate.

Sambrook, Richard (2018) (toim.). Global Teamwork. The Rise of Collaboration in Investigative Journalism. University of Oxford: Reuters Institute for the Study of Journalism.

Sankari, Valtteri \& Wiberg, Matti (2019). Tarkistuksissa vielä parannettavaa: Ylen faktantarkistuksen tarkistus. Media Q Viestintä 42:4, 235-245. Saatavilla: https://journal.fi/mediaviestinta/article/view/88452 (luettu 26.8.2020).

Sanomalehtien liitto (2018). Yhteisöllistyvä media. Saatavilla: https://www.sanomalehdet.fi/ajankohtaista/sosiaalisen-median-laatumielikuva-on-heikentynyt/ (luettu 8.9.2020).

Schetzer, Alana (2019). Government's making "fake news" a crime risk stifling real journalism accidentally or intentionally. Nieman Lab 11.7.2019. Saatavilla: https://www.niemanlab.org/2019/o7/ governments-making-fake-news-a-crime-risk-stifling-real-journalism-accidentally-or-intentionally/ (luettu 8.9.2020).

Schudson, Michael (2008). The 'Lippmann-Dewey debate' and the invention of Walter Lippmann as an anti-democrat 1986-1996. International Journal of Communication 2, 1031-1042.

Schudson, Michael (1978). Discovering the News: A Social History of American Newspapers. New York: Basic Books.

Seth, Lewis C. (2020). Lack of trust in the news media, institutional weakness, and relational journalism as a potential way forward. Journalism 21:3, 345-348. https://doi.org/10.1177/1464884918807597

Sivonen, Jukka \& Saarinen, Arttu (2018). Puolueiden kannattajien luottamus mediaan. Yhteiskuntapolitiikka 3. Saatavilla: https://www.julkari.fi/handle/10024/137179 (luettu 8.9.2020).

Stahl, Roger (2010). Militainment, Inc.: War, media, and popular culture. New York, NY: Routledge. https://doi.org/10.4324/9780203879603

Stovall, James G. (2004). Journalism: Who, What, When. Where, Why, and How. New York: Allyn \& Bacon.

Stuhr, John J. (2019). Dewey's pragmatic politics: Power, limits, and realism about democracy as a way of life. Teoksessa: Fesmire, Steven (toim.). The Oxford Handbook of Dewey. Oxford: Oxford University Press, 291-312. https://doi.org/10.1093/oxfordhb/9780190491192.013.33

Tandoc, Edson C. Jr; Lim, Zheng Wei \& Ling, Richard (2018). Defining "fake news". A typology of scholarly definitions. Digital Journalism 6:2, 137-153. https://doi.org/10.1080/21670811.2017.1360143

Tervonen, Ilkka (1986). Objektiivisuus ja informatiivisuus: journalismin tiedollisten ominaisuuksien tarkastelua kahden käsitteen kannalta. Tampere: Tampereen yliopisto.

Tiedebarometri 2019. Saatavilla: https://www.tieteentiedotus.fi/files/Tiedebarometri_2019.pdf (luettu 8.9.2020).

Tiilikka, Päivi (2008). Journalistin sananvapaus. Helsinki: WSOYpro.

Tiilikka, Päivi (2007). Sananvapaus ja yksilönsuoja: lehtiartikkelin aiheuttaman kärsimyksen korvaaminen. Helsinki: WSOYpro.

Tuchman, Gaye (1978). Making News: The Study in the Construction of Reality. New York: Free Press.

Vihma, Antto; Hartikainen, Jarno; Ikäheimo, Hannu-Pekka \& Seuri, Olli (2018). Totuuden jälkeen. Miten media selviää algoritmien ja paskapuheen aikana. Helsinki: Teos.

Vosoughi, Soroush; Roy, Deb \& Aral, Sinai (2018). The spread of true and false news online. Science 359:6380, 1146-1151. https://10.1126/science.aap9559

Väliverronen, Esa (toim.) (2009). Journalismi murroksessa. Helsinki: Gaudeamus. 
Ward, Stephen J. A. (2010a). Inventing Objectivity: New philosophical foundations. Teoksessa: Meyers, Christopher (toim.). Journalism Ethics: A Philosophical Approach. Oxford: Oxford University Press, 137-152. https://doi.org/10.1093/acprof:0so/9780195370805.003.0009

Ward, Stephen J. A. (2010b). Global Journalism Ethics. Montreal: McGill-Queen's University Press.

Ward, Stephen. J. A. (2004). The Invention of Journalism Ethics: The Path to Objectivity and Beyond. Montreal: McGill-Queen's University Press.

Ward, Stephen J.A. (1998). An Answer to Martin Bell: Objectivity and Attachment in Journalism. The Harvard International Journal of Press/Politics 3:3), 121-125. https://doi.org/10.1177/1081180X98003003009

Wiio, Osmo A. (1975). Onko objektiivista joukkoviestintää? Kanava 5, 273-281.

Williams, Bernard (2002). Truth and Truthfulness: An Essay in Genealogy. Princeton: Princeton University Press.

Wittgenstein, Ludwig (1999 [1953]). Filosofisia tutkimuksia. Suomentanut Heikki Nyman. Helsinki: WSOY. Yle (27.5.2020). Twitter puuttui ensimmäistä kertaa Trumpin tviitteihin - presidentin mukaan yhtiö sekaantuu vaaleihin. Saatavilla: https://yle.fi/uutiset/3-11369805 (luettu 8.9.2020). 